\title{
Kontribusi Kedisiplinan Belajar, Pola Asuh, dan Fasilitas Belajar Terhadap Hasil Belajar Matematika Selama Pembelajaran Daring
}

\author{
N.L.Sudiartini ${ }^{1 *}$, I.G.P.Suharta ${ }^{2}$, I.G.P.Sudiarta ${ }^{3}$ iD \\ ${ }^{1,2,3}$ Program Studi Jurusan Pendidikan Matematika Pascasarjana, Universitas Pendidikan Ganesha, Singaraja, Indonesia \\ *Corresponding author: niluh.sudiartini36@gmail.com
}

\begin{abstract}
Abstrak
Pembelajaran daring berdampak terhadap perubahan sikap isolasi social, kurangnya interaktivitas, partisiapsi dan keterbatasan umpan balik.Penelitian ini bertujuan untuk mengetahui seberapa besar kontribusi kedisiplinan belajar, pola asuh,dan fasilitas belajar terhadap hasil belajar matematika selama pembelajaran daring yang dimiliki siswa terhadap hasil belajar matematika. Jenis penelitian ini adalah penelitian ex-post facto. Populasi dalam penelitian ini adalah seluruh siswa kelas IV SD yang mengikuti pembelajaran daring berjumlah 229 orang. Jumlah sampel dihitung dengan rumus Slovin berjumlah 146 siswa. Metode pengumpulan data menggunakan metode non tes dengan menggunakan kuesioner melalui google forms. Teknik analisi data menggunakan statistik analisis regresi. Hasil penelitian dapat menunjukkan bahwa terdapat kontribusi disiplin belajar siswa, pola asuh orang tua dan fasilitas belajar secara dan besar kontribusi disiplin belajar siswa, pola asuh orang tua dan fasilitas belajar secara bersama terhadap hasil belajar siswa adalah $85 \%$ dan $15 \%$ dipengaruhi oleh faktor hasil belajar yang lainnya. Terdapat kontribusi kedisiplin belajar siswa dan besar kontribusi kedisiplin belajar siswa, terhadap hasil belajar siswa adalah 30\% dan $70 \%$ dipengaruhi oleh faktor hasil belajar yang lainnya. Terdapat kontribusi pola asuh orang tua dan sesar kontribusi pola asuh orang tua terhadap hasil belajar siswa adalah 45\% dan 55\% dipengaruhi oleh faktor hasil belajar yang lainnya. Terdapat kontribusi fasilitas belajar dan besar kontribusi fasilitas belajar terhadap hasil belajar siswa adalah 10\% dan 90\% dipengaruhi oleh faktor hasil belajar yang lainnya.
\end{abstract}

Kata kunci: Pembelajaran Daring, Kedisiplinan, Pola Asuh

\section{Abstract}

This study aims to determine how muchthe contribution of discipline, parenting style, and facilities together to mathematics learning outcomes. The population in this study were 229 grade students of SD Regency who took online learning. This research is an ex-post facto study using a questionnaire via google forms which is distributed to 146 students. Based on the results and discussion of the research it can be concluded that: (1) there is a contribution of student learning discipline, parenting styles and learning facilities and the contribution of student learning discipline, parenting parents and learning facilities collectively to student learning outcomes is $85 \%$ and $15 \%$ is influenced by other learning outcome factors. There is a contribution of student learning discipline and the contribution of student learning discipline, to student learning outcomes is $30 \%$ and $70 \%$ is influenced by other learning outcome factors. There is a contribution of parenting style and contribution of parenting parents to student learning outcomes is $45 \%$ and $55 \%$ is influenced by other learning outcome factors. There is a contribution of learning facilities and the contribution of learning facilities to student learning outcomes is $10 \%$ and $90 \%$ is influenced by other learning outcome factors.

Keywords: Online Learning, Discipline, Parenting

$\begin{array}{ll}\text { History: } & \\ \text { Received } & : \text { 13 Januari } 2021 \\ \text { Revised } & : \text { 22 Januari } 2021 \\ \text { Accepted } & : \text { 3 Maret } 2021 \\ \text { Published } & : 25 \text { Maret } 2021\end{array}$

Publisher: Undiksha Press

Licensed: This work is licensed under

a Creative Commons Attribution 4.0 License

Published : 25 Maret 2021

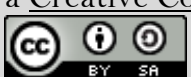

\section{Pendahuluan}

Pendidikan saat ini sedang menghadapi masalah yang menuntut pemerintah mengambil kebijakan yang tepat tentang bagaimana pendidikan itu harus dilakukan ditengah 
pandemic covid-19. Pandemic covid-19 memberikan dampak terhadap perubahan tatanan kehidupan manusia, termasuk perubahan dalam bidang pendidikan (Anugrahana, 2020; De Brouwer,2020) Pemerintah juga mengeluarkan kebijakan untuk "stay at home" sehingga pembelajaran yang dilakukan secara tatap muka, harus menyesuaikan dengan kebijakan tersebut dan mengubah pelajaran dengan metode pembelajaran daring. Pembelajaran daring/online merupakan suatu kegiatan belajar yang membutuhkan jaringan internet dengan konektivitas, aksesibilitas, fleksibilitas, serta kemampuan untuk memunculkan berbagai jenis interaksi pembelajaran (Sourial, Longo, C., Vedel, et al., 2018). Pembelajaran daring adalah pembelajaran yang dilakukan dengan bantuan internet, yang memberikan kesempatan kepada siswa untuk belajar lebih mandiri tanpa adanya batas ruang dan waktu (O'Doherty et al., 2018). Dengan adanya pembelajaran daring memberikan kesepatan peserta didik untuk bertukar pendapat dengan orang lain dan memberikan kesempatan kepada peserta didik untuk belajar mandiri (Hwang et al., 2020). Alat bantu yang bisa digunakan dalam proses pembelajaran daring adalah google meet, google room, google classroom, WhatsApp's (WA), dan social media (Chang et al., 2020). Segala kegiatan yang dilakukan, seperti pemberian tugas-tugas diberikan melalui WhatsApp's, Jika memang peserta didik masih belum memahami maka guru juga akan menambahkan dengan mengirimkan video ataupun melakukan WhatsApp's Video Call dengan peserta didik, penggumpulan tugaspun lebih memudahkan peserta didik melalui pesan WhatsApp's.

Namun, tidak selamanya pembelajaran online/daring tersebut berdampak positif, pembelajaran daring berdampak terhadap perubahan sikap isolasi social, kurangnya interaktivitas, partisiapsi dan keterbatasan umpan balik. Kurang siapnya orang tua dalam menghadapi pembelajaran online, pembelajaran online tidak mempunyai suasan formal seperti pembelajaran tradisional, pada pembelajaran online tidak terjadi interaksi social sesama peserta didik (Asmuni, 2020). Banyak anak yang tidak melakukan pembelajaran online, melakukan aktivitas yang lain selain belajar seperti bermain game, social media dan lebih banyak menonton youtube serta kegiatan yang lain yang menunjukkan adanya kecanduan "gawe". Serta masalah yang lain adalah dengan pemberian masalah yang terlalu rumit akan menyebakan peserta didik frustasi dan tidak ingin belajar. Masalah ini terjadi pada pelajaran matematika. Matematika merupakan salah satu mata pembelajaran yang berperan penting dalam kehidupan sehari-hari (Intan \& Hidayat, 2018). Matematika dikatakan penting karena dijadikan sebagai suatu cara berfikir siswa dalam kehidupan sehari- hari (Nur, 2016). Mengingat pentingnya pembelajaran matematika, maka pembelajaran matematika haruslah lebih banyak siswalah aktif dalam menemukan dan membangun pengetahuannya sendiri. Pembelajaran matematika membutuhkan bantuan teknologi untuk menyampaikan materi yang membentukkan pemahaman dan konsep yang bersifat kompleks (Mulyati \& Evendi, 2020)

Beberapa indikator yang menunjukkan rendahnya kualitas proses belajar mengajar matematika antara lain: 1) kurangnya kesiapan siswa sebelum proses belajar mengajar matematika dimulai, 2) masih rendahnya partisipasi siswa dalam proses belajar mengajar matematika, 3) kurang optimalnya pelaksanaan belajar mengajar matematika di sekolah (Wana et al., 2017). Berdasarkan jabaran tersebut dapat dikatakan secara umum pembelajaran matematika masih perlu diperhatikan apalagi ditengah pandemic saat ini. Jika masalah ini dibiarkan akan berdampak terhadap hasil belajar. Kerberhasilan pembelajaran secara daring tidak terlepas dari fasilitas pembelajaran, disiplin siswa, model pembelajaran strategi pembelajaran, motivasi dan sikap tegas (Abe, 2020). Kedisiplinan sebagai kesadaran individu terhadap tugas/kewajiban/aturan yang nampak pada perilaku individu dalam mengendalikan dan mengarahkan diri sesuai aturan yang berlaku di lingkungannya (Kristin \& Kencana, 2019). Disiplin termasuk dalam faktor internal yang dapat memengaruhi pencapaian prestasi belajar siswa, tanpa adanya sikap disiplin yang tinggi maka proses pembelajaran akan 
menjadi sebuah aktivitas yang kurang bermakna (Anggraini et al., 2017). Jadi, dapat dikatakan bahwa dengan adanya disiplin belajar siswa akan dapat mengatur proses pembelajaan dan secara tidak langsung akan berpengaruh terhadap hasil belajar siswa.

Selain disiplin belajar faktor penentu keberhasilan siswa dalam proses pembelajaran adalah pola asuh orang tua. Pola asuh yang diterapkan orang tua di lingkungan keluarga mampu mempengaruhi kepribadian, selain itu juga kedisiplinan seorang siswa di lingkungan sekolah. Pola asuh orang tua mempengaruhi bentuk kepribadian dan karakteristik pada anak secara keseluruhan. Keberadaan dan sikap orang tua pun menjadikan cerminan bagi seorang anak (Siegal et al., 2015). Pola pengasuhan anak sangat di pengeruhi oleh kontrol dan kehangatan orang tua serta nilai-nilai budaya juga menentukan bagaimana orang tua mengasuh anak (Luo et al., 2020; Vélez-Agosto et al., 2017). Pola pengasuhan anak berhubungan dengan perhatian anak, pola asuh yang positif akan memberikan kesempatan kepada anakan untuk fokus dengan apa yang mereka kerjakan tanpa adanya rasa cemas (Chen et al., 2020). Dengan adanya pola asuh akan memperbaiki atau membentuk kesehatan psikologi anak (Khodabakhsh et al., 2014). Cara orang tua dalam mengatur emosi dan prilaku akan memberikan pengaruh yang positif terhadap hubungan orang tua dan anak yang (Surya Erofiana et al., 2021). Anak yang sehat psikologi akan membuat siswa mengikuti pembelajaran dengan senang hati dan tentunya ini sangat mempengaruhi dari hasil belajar siswa.

Selain dua faktor yang yang sudah dibahas sebelumnya, salah satu faktor yang penting dalam terwujudnya pembelajaran daring yang berkulitas adalalah fasilitas. Fasilitas adalah segala alat bantu yang dibutuhkan untuk mempermudah proses pembelajaran. Fasilitas pendidikan meliputi semua fasilitas yang diperlukan dalam proses belajar mengajar baik yang bergerak maupun yang tidak bergerak agar pencapaian tujuan pendidikan dapat berjalan lancar, teratur, efektif, dan efisien sehingga siswa dapat mencapai hasil belajar yang optimal (Cynthia et al., 2015). Peranan pemanfaatan fasilitas dalam kegiatan belajar mengajar sangatlah penting, sebab pemanfaatan fasilitas belajar mencakup seluruh pemanfaatan alatalat yang menunjang kegiatan belajar siswa (Wulandari, 2019). Apalagi saat ini, proses pembelajaran daring sangat membutuhkan fasilitas seperti smartphone, laptop, ataupun tablet yang dapat digunakan untuk mengakses informasi (Sourial, Longo, et al., 2018).

Berdasarkan jabaran tersebut dapat dikatakan bahwa dengan adanya fasilitas yang memadai akan sangat berdampak terhadap proses pembelajaran yang dilakukan. Kerberhasilan pembelajaran secara daring tidak terlepas dari fasilitas pembelajaran, disiplin siswa, model pembelajaran strategi pembelajaran, motivasi dan sikap tegas (Abe, 2020). Seperti yang sudah dijabarkan sebelumnya. Masing-masing faktor seperti disiplin belajar, pola asuh dan fasilatas mempengaruhi hasil belajar siswa secara parsial. Oleh sebab itu pernyataan ini harus kembali dibuktikan, apakah dalam pembelajaran daring faktor-faktor tersebut mempengaruhi pembelajaran. Tujuan dari penelitian ini, untuk mengetahui apakah terdapat kontribusi antara kedisiplinan, pola asuh dan fasilitas belajar terhadap hasil belajar matematika di kelas IV SD dan seberapa besar kontribusinya.

\section{Metode}

Penelitian ini merupakan penelitian ex-post facto (pengukuran setelah kejadian), karena data penelitian baik variabel bebas maupun variabel terikat telah terjadi sebelum penelitian ini diadakan. Penggunaan pendekatan expost facto didasari oleh dua alasan yaitu: (1) penelitian ini bermaksud untuk menguji apakah yang terjadi pada subjek penelitian, (2) penelitian ini bermaksud untuk menyelidiki apakah satu atau dua atau lebih kondisi yang sudah terjadi menyebabkan perbedaan perilaku pada subjek penelitian. Populasi dalam penelitian ini adalah siswa SD kelas IV Gugus V Kecamatan Buleleng 2020/2021 yang terdiri atas 9 sekolah yaiu SDN 1, 2 dan 3 Sambangan. SDN 1, 2, 3, 4, 5, dan 6 Panji. Total Siswa 
Kelas IV SD adalah 229. Pada penelitian ini, jumlah sampel akan dihitung dengan rumus Slovin. Mengingat bahwa jawaban yang akan dihasilkan tidak pasti dan jumlah populasi yang ada di Gusus V buleleng berada pada katagori besar. Berdasarkan perhitungan yang dilakukan jumlah samplenya adalah 133 orang. Dengan perhitungan agar setiap unit diwakilkan akan kembali dihitung sehinga dapat dijabarkan hasil sampel sesuai dengan tabel 1 .

Tabel 1. Jumlah Populasi dan anggota sampel

\begin{tabular}{cccc}
\hline No. & Unit Sekolah & Jumlah populasi & Jumlah Anggota Sampel \\
\hline 1 & SD N 1 Panji & 26 & 17 \\
2 & SD N 2 Panji & 20 & 12 \\
3 & SD N 3 Panji & 27 & 17 \\
4 & SD N 4 Panji & 20 & 12 \\
5 & SD N 5 Panji & 25 & 16 \\
6 & SD N 6 Panji & 23 & 15 \\
7 & SD N 1 Sambangan & 28 & 19 \\
8 & SD N 2 Sambangan & 30 & 19 \\
9 & SD N 3 Sambangan & 30 & 19 \\
\hline & Total & $\mathbf{2 2 9}$ & $\mathbf{1 4 6}$
\end{tabular}

Metode pengumpulan data dalam penelitian ini menggunakan tehnik angket dan tehnik dokumentasi. Tehnik angket digunakan untuk menjaring data kedisiplinan, pola asuh orang tua, dan fasilitas belajar. Sedangkan tehnik dokumentasi digunakan untuk mengumpulkan data hasil belajar siswa setelah mengikuti pembelajaran. Berbagai data yang diperoleh tersebut kemudian dilakukan identifikasi untuk memilah-milah data yang benarbenar bermanfaat. Dari berbagai konsep dan teori yang dikumpulkan kemudian dilakukan identifikasi terhadap keseluruhan variabel yang diteliti, baik variabel bebas (independent variable) maupun variabel terikat (dependent variable). Selanjutnya dilaksanakan perhitungan dengan model statistik analisis regresi sederhana maupun ganda karena teridiri dari tiga variabel bebas. Keseluruhan hasil perhitungan tersebut pada dasarnya memberikan informasi tentang disiplin belajar siswa, pola asuh orang tua dan fasilitas belajar terhadap hasil belajar siswa dalam pembelajaran daring.

\section{Hasil dan Pembahasan}

Untuk mendapatkan gambaran mengenai karakteristik distribusi skor dari masingmasing variabel. Untuk pengujian prasyarat analisis data, pertama dilakukan uji normalitas menggunakan Teknik Kormogorov Smirnov diperoleh nilai $\mathrm{p}>0,05$ yang artinya seluruh kelompok data berasal dari populasi yang berdistribusi normal. Kedua, dilanjutkan dengan melakukan uji lineritas garis regresi menggunakan uji $\mathrm{F}$ didapatkan untuk $\mathrm{p}$ Deviation from Linearity dengan sig. > 0,05 artinya hubungan antara kedisiplinan belajar, pola asuh, fasilitas belajar dengan hasil belajar mempunyai hubungan yang linier. Ketiga, dilakukan uji multikolinieritas dikenakan terhadap sesama variabel bebas yaitu skor kedisiplinan belajar $\left(\mathrm{X}_{1}\right)$, skor pola asuh $\left(\mathrm{X}_{2}\right)$, dan skor fasilitas belajar $\left(\mathrm{X}_{3}\right)$. Berdasarkan hasil perhitungan diperoleh $\mathrm{r}_{\mathrm{xx}}$ antara sesama variabel bebas kurang dari 0,800 ; ini berarti antara sesama variabel bebas tidak terjadi multikolinieritas (nirkolinier). Keempat, untuk mengetahui ada atau tidaknya penyimpangan asumsi klasik heteroskedastisitas maka dilakukan uji heteroskedastisitas menggunakan uji Glesjer. Seperti pada Tabel 2. 
Tabel 2. Hasil Uji Heteroskedastisitas dengan Uji Glesjer

\begin{tabular}{|c|c|c|c|c|c|c|}
\hline & \multirow[t]{2}{*}{ Model } & \multicolumn{2}{|c|}{$\begin{array}{c}\text { Unstandardized } \\
\text { Coefficients }\end{array}$} & \multirow{2}{*}{$\begin{array}{c}\text { Standardized } \\
\text { Coefficients } \\
\text { Beta }\end{array}$} & \multirow[t]{2}{*}{$\mathbf{t}$} & \multirow[t]{2}{*}{ Sig. } \\
\hline & & B & Std. Error & & & \\
\hline \multirow{4}{*}{1} & (Constant) & $-4.328 \mathrm{E}-15$ & 5.039 & & 0,000 & 1.000 \\
\hline & Kedisiplinan_belajar & 0,000 & 0,043 & 0,000 & 0,000 & 1.000 \\
\hline & Pola_asuh & 0,000 & 0,040 & 0,000 & 0,000 & 1.000 \\
\hline & Fasilitas_belajar & 0,000 & 0,042 & 0,000 & 0,000 & 1.000 \\
\hline
\end{tabular}

Berdasarkan hasil uji pada Tabel 1 dapat dikatakan bahwa tidak terjadinya heteroskedastisitas antar variable hal ini dapat dilihat dengan Nilai Sig. masing-masing Variabel 1.00, ini lebih dari 0,05. Sehingga $\mathrm{H}_{\mathrm{o}}$ diterima tidak ada heteroskedastisitas dalam model Regresi. Terakhir, dilakukan pengujian hipotesis dalam penelitian ini adalah: 1) Seberapa besar kontribusi disiplin belajar siswa, pola asuh orang tua dan fasilitas belajar secara bersama terhadap hasil belajar siswa dalam pembelajaran daring di SD kelas IV di Gugus V Kabupaten Buleleng. 2) Seberapa besar kontribusi disiplin belajar siswa terhadap hasil belajar siswa dalam pembelajaran daring di SD kelas IV di Gugus V Kabupaten Buleleng. 2) Seberapa besar kontribusi pola asuh terhadap hasil belajar siswa dalam pembelajaran daring di SD kelas IV di Gugus V Kabupaten Buleleng. 3) Seberapa besar kontribusi fasilitas belajar terhadap hasil belajar siswa dalam pembelajaran daring di SD kelas IV di Gugus V Kabupaten Buleleng. Setelah data dianalisis diperoleh ringkasan hasil analisis seperti tampak pada tabel di bawah ini. Hasil analisis hipotesis dengan regresi Gabda dapat di jabarkan pada Tabel 3 dan Tabel 4.

Berdasarkan analisis konstribusi antar variabel pada Tabel 3 dan 4, dapat dijelaskan sebagai berikut. Hipotesis pertama, berdasarkan hasil analisis regresi, yang tercantum pada Tabel 2 menunjukkan bahwa terdapat kontribusi disiplin belajar siswa, pola asuh orang tua dan fasilitas belajar secara bersama terhadap hasil belajar siswa dalam pembelajaran daring di SD kelas IV di Gugus V Kabupaten Buleleng. Hal ini ditunjukkan dengan Nilai F=126,291 dengan $\mathrm{p}=0,00<0,05$ yang meyatakan bahwa terdapat kontribusi disiplin belajar siswa, pola asuh orang tua dan fasilitas belajar secara bersama terhadap hasil belajar siswa dalam pembelajaran daring di SD kelas IV di Gugus V Kabupaten Buleleng. Besar kontribusi disiplin belajar siswa, pola asuh orang tua dan fasilitas belajar secara bersama terhadap hasil belajar siswa adalah $85 \%$ dan $15 \%$ dipengaruhi oleh faktor hasil belajar yang lainnya.

Tabel 3. Ringkasan Hasil Analisis Regresi

\begin{tabular}{|c|c|c|c|c|c|c|}
\hline & \multirow[t]{2}{*}{ Model } & \multicolumn{2}{|c|}{$\begin{array}{c}\text { Unstandardized } \\
\text { Coefficients }\end{array}$} & \multirow{2}{*}{$\begin{array}{c}\begin{array}{c}\text { Standardized } \\
\text { Coefficients }\end{array} \\
\text { Beta }\end{array}$} & \multirow[t]{2}{*}{$\mathbf{t}$} & \multirow[t]{2}{*}{ Sig. } \\
\hline & & B & Std. Error & & & \\
\hline \multirow[t]{4}{*}{1} & (Constant) & 15.994 & 5.039 & & 3.174 & .002 \\
\hline & $\begin{array}{l}\text { Kedisiplinan_belaja } \\
\mathrm{r}\end{array}$ & .818 & .043 & .919 & 0,405 & .000 \\
\hline & Pola_asuh & .784 & .040 & .853 & 0.443 & .000 \\
\hline & Fasilitas_belajar & .612 & .042 & 1713 & 0.286 & .000 \\
\hline & Dependent Variable: $\mathrm{H}$ & beajar & & & & \\
\hline
\end{tabular}


Tabel 4. Ringkasan Hasil Analisis Data Kontribusi Antar-Variabel

\begin{tabular}{|c|c|c|c|c|}
\hline & $\begin{array}{c}\text { Persamaan Garis } \\
\text { Regresi }\end{array}$ & $\begin{array}{l}\text { Koefisien } \\
\text { Korelasi }\end{array}$ & $\begin{array}{l}\text { Kontribus } \\
\quad \text { i }(\%)\end{array}$ & $\begin{array}{c}\text { Sumbangan } \\
\text { Efektif } \\
(\mathrm{SE})(\%) \\
\end{array}$ \\
\hline $\mathrm{X}_{1}$ dengan $\mathrm{Y}$ & $\widehat{Y}=15,585+0,305 \mathrm{X}_{1}$ & 0,213 & $30 \%$ & $26 \%$ \\
\hline $\mathrm{X}_{2}$ dengan $\mathrm{Y}$ & $\widehat{Y}=16,450+0,785 \mathrm{X}_{2}$ & 0,857 & $45 \%$ & $47,19 \%$ \\
\hline $\mathrm{X}_{3}$ dengan $\mathrm{Y}$ & $\widehat{Y}=18,964+0,508 \mathrm{X}_{3}$ & 0,160 & $10 \%$ & $15 \%$ \\
\hline $\begin{array}{l}\mathrm{X}_{1}, \quad \mathrm{X}_{2} \text {, dan } \\
\text { dengan } \mathrm{Y}\end{array}$ & $\begin{array}{l}Y= \\
15,994+0,818 \mathrm{X}_{1}+0,784 \mathrm{X}_{2}+ \\
0,612 \mathrm{X}_{3}\end{array}$ & 0,853 & $85 \%$ & $87 \%$ \\
\hline
\end{tabular}
Keterangan
Signifikan dan linier
Signifikan

Keterangan: $\mathrm{X}_{1}=$ Skor kedisiplinan belajar; $\mathrm{X}_{2}=$ Skor pola asuh orang tua; $\mathrm{X}_{3}=$ Skor fasilitas belajar; Y= Skor hasil belajar

Hipotesis kedua, berdasarkan hasil analisis regresi, yang tercantum pada Tabel 3 menunjukkan bahwa terdapat kontribusi kedisiplin belajar siswa, terhadap hasil belajar siswa dalam pembelajaran daring di SD kelas IV di Gugus V Kabupaten Buleleng. Hal ini ditunjukkan dengan $\mathrm{p}=0,00<0,05$ yang meyatakan bahwa terdapat kontribusi kedisiplin belajar siswa, terhadap hasil belajar siswa dalam pembelajaran daring di SD kelas IV di Gugus V Kabupaten Buleleng. Besar kontribusi kedisiplin belajar siswa, terhadap hasil belajar siswa adalah $30 \%$ dan $70 \%$ dipengaruhi oleh faktor hasil belajar yang lainnya. Hipotesis ketiga, berdasarkan hasil analisis regresi, yang tercantum pada Tabel 3 menunjukkan bahwa terdapat kontribusi pola asuh orang tua terhadap hasil belajar siswa dalam pembelajaran daring di SD kelas IV di Gugus V Kabupaten Buleleng. Hal ini ditunjukkan dengan $\mathrm{p}=0,00<0,05$ yang meyatakan bahwa terdapat kontribusi pola asuh orang tua, terhadap hasil belajar siswa dalam pembelajaran daring di SD kelas IV di Gugus V Kabupaten Buleleng. Besar kontribusi pola asuh orang tua terhadap hasil belajar siswa adalah 45\% dan 55\% dipengaruhi oleh faktor hasil belajar yang lainnya. Hipotesis keempat, berdasarkan hasil analisis regresi, yang tercantum pada Tabel 3 menunjukkan bahwa terdapat kontribusi fasilitas belajar terhadap hasil belajar siswa dalam pembelajaran daring di SD kelas IV di Gugus V Kabupaten Buleleng. Hal ini ditunjukkan dengan $\mathrm{p}=0,00<0,05$ yang meyatakan bahwa terdapat kontribusi fasilitas belajar, terhadap hasil belajar siswa dalam pembelajaran daring di SD kelas IV di Gugus V Kabupaten Buleleng. Besar kontribusi fasilitas belajar terhadap hasil belajar siswa adalah $10 \%$ dan $90 \%$ dipengaruhi oleh faktor hasil belajar yang lainnya.

Berdasarkan hasil penelitian menunjukkan terdapat kontribusi disiplin belajar siswa, pola asuh orang tua dan fasilitas belajar secara bersama terhadap hasil belajar siswa dalam pembelajaran daring di SD kelas IV di Gugus V Kabupaten Buleleng. Besar kontribusi disiplin belajar siswa, pola asuh orang tua dan fasilitas belajar secara bersama terhadap hasil belajar siswa adalah $85 \%$ dan $15 \%$. Jika dilihat dari besarnya kontribusi dari ketiga faktor tersebut, ditemukan bahwa disiplin belajar memberi kontribusi yang besar dibandingkan dengan intensitas pola asuh dan fasilitas belajar. Karena itu, menjadi perlu untuk memperhatikan Selanjutnya perlu juga perhatian pada peningkatan intensitas pola asuh dan disiplin belajar. Karena itu, hasil belajar siswa tentu juga dipengaruhi oleh disiplin belajar, pola asuh dan fasilitas belajar. Karena itu, agar hasil belajar siswa dapat meningkat maka 
perlu pendampingan, bimbingan yang lebih intens dari orang tua terhadap siswa di rumah serta guru disekolah.

Berdasarkan hasil penelitian, terdapat kontribusi disiplin belajar siswa terhadap hasil belajar siswa dalam pembelajaran daring. Hal ini ditunjukkan dengan $p=0,00<0,05$ yang menyatakan bahwa terdapat kontribusi kedisiplin belajar siswa, terhadap hasil belajar siswa dalam pembelajaran daring di SD kelas IV di Gugus V Kabupaten Buleleng. Besar kontribusi kedisiplin belajar siswa, terhadap hasil belajar siswa adalah 30\% dan $70 \%$ dipengaruhi oleh faktor hasil belajar yang lainnya. Hal ini terjadi, apabila seorang siswa dapat mendisiplinkan diri, sehingga dapat hidup teratur dan mengerjakan tugas tepat pada waktunya. Siswa tidak akan mengalami kesulitan apabila menghadapi pelajaran atau masalah-masalah. Disiplin menjadi prasyarat bagi pembentukan sikap, perilaku dan tata kehidupan berdisiplin yang akan mengantar seorang siswa sukses dalam belajar ketika bekerja (Haryuni, 2013). Disiplin belajar yang tinggi akan mendorong siswa untuk mendapatkan hasil belajar yang baik. Hal ini dikarenakan untuk mendapatkan nilai yang baik diperlukan peraturan tata tertib yang menunjang proses belajar siswa. Disiplin dapat diartikan patuh terhadap ketentuan-ketentuan, peraturanperaturan dan norma-norma yang berlaku (Mabuka, 2021). Disiplin memiliki beberapa unsur yang diantaranya mentaati peraturan, norma, dan hukum yang berlaku sebagai alat untuk mempengaruhi, mengubah, dan membina kepribadian seseorang guna mentaati peraturan tersebut.

Terdapat kontribusi pola asuh orang tua terhadap hasil belajar siswa dalam pembelajaran daring di SD kelas IV di Gugus V Kabupaten Buleleng. Hal ini ditunjukkan dengan $\mathrm{p}=0,00<0,05$ yang meyatakan bahwa terdapat kontribusi kedisiplin belajar siswa, terhadap hasil belajar siswa dalam pembelajaran daring di SD kelas IV di Gugus V Kabupaten Buleleng. Besar kontribusi kedisiplin belajar siswa, terhadap hasil belajar siswa adalah 30\% dan $70 \%$ dipengaruhi oleh faktor hasil belajar yang lainnya. Pengasuhan orang tua sangat berpengaruh terhadap hasil belajar siswa di sekolah (Puncangan, 2017). Pengasuhan yang baik dan tepat yang dilakukan oleh orangtua akan mengoptimalkan hasil belajar siswa, sehingga orang tua harus memahami pola asuh apa yang dibutuhkan sesuai dengan kondisi. Dengan kondisi dan lingkungan yang nyaman dan harmonis akan membentuk tingkah laku yang baik dari anak, karena tingkah laku anak merupakan cerminan dari pengasuhan orang tua.

Terdapat kontribusi fasilitas belajar terhadap hasil belajar siswa dalam pembelajaran daring di SD kelas IV di Gugus V Kabupaten Buleleng. Hal ini ditunjukkan dengan $p=0,00$ $<0,05$ yang meyatakan bahwa terdapat kontribusi fasilitas belajar, terhadap hasil belajar siswa dalam pembelajaran daring di SD kelas IV di Gugus V Kabupaten Buleleng. Besar kontribusi fasilitas belajar terhadap hasil belajar siswa adalah $10 \%$ dan $90 \%$ dipengaruhi oleh faktor hasil belajar yang lainnya. Faslitas belajar yang cukup akan memungkinkan memperlancar penguasaan siswa terhadap mata pelajaran yang dipelajarinya, memungkinkan memberikan kesempatan yang luas bagi siswa untuk melakukan kegiatan belajar yang teratur dan akan menimbulkan suasana yang menyenangkan dan menggairahkan bagi diri siswa untuk berprestasi baik. Fasilitas belajar dapat memberikan kemudahan bagi siswa dalam memecahkan berbagai permasalahan yang terjadi ketika akan mempelajari dan memahami tugas yang diberikan oleh guru (Wardani, 2021).

Temuan penelitian ini diperkuat dengan pernyataan pola asuh orang tua berhubungan secara siginifikan terhadap hasil belajar siswa (Pada, 2021; Pucangan, 2017). Temuan lain menyatakan terdapat pengaruh disiplin belajar terhadap hasil belajar (Handayani \& Subakti, 2020; Novalinda et al., 2020)(Handayani \& Subakti, 2020). Fasilitas dan disiplin belajar siswa memiliki kontribusi yang signifikan terhadap hasil belajar siswa (Dianah, 2017). Oleh karena itu kelengkapan fasilitas dan tingkat disiplin siswa dan pola asuh orang tua perlu ditingkatkan serta perlu mendapat perhatian dari berbagai pihak. Disiplin menjadi kunci 
mencapai kesuksesan dalam segala hal. Sebagai implikasi dari penelitian ini bagi seorang guru sebaiknya mampu meningkatkan sikap kedisiplinan dalam bekerja sehingga kualitas dari kinerja guru dapat meningkat dan mutu pendidikan juga dapat meningkat. Selain itu peningkatan disiplin juga perlu dilakukan oleh siswa sehingga dapat meningkatkan hasil belajarnya. Peningkatan tersebut tidak hanya dirasakan oleh guru atau siswa itu sendiri tetapi juga dapat dirasakan oleh seluruh warga sekolah. Penerapan sikap disiplin kerja, pola asuh orang tua dan fasilitas belajar dilingkungan sekolah dasar dapat dijadikan acuan bagi kepala sekolah, sehingga dapat memberikan masukan bagi para siswa agar lebih disiplin belajar, dan kepada lembaga pendidikan memperhatikan fasilitas pembelajaran sehingga pelaksanaan pembelajaran menjadi optimal. Dengan demikian melalui disiplin belajar, pola asuh orang tua, dan fasilitas belajar yang tinggi dapat meningkat hasil belajar serta dapat meningkatkan kualitas dan mutu Pendidikan.

\section{Simpulan}

Berdasarkan hasil analisis data maka dapat disimpulkan bahwa disiplin belajar siswa, pola asuh orang tua dan fasilitas belajar memiliki hubungan yang signifikan dengan hasil belajar siswa dalam pembelajaran daring. Adapun penerapan sikap disiplin belajar siswa, pola asuh orang tua dan peningkatan fasilitas belajar yang baik akan berdampak terhadap hasil belajar siswa yang baik. Hal tersebut dapat menjadikan kualitas dan mutu pendidikan yang baik.

\section{Daftar Rujukan}

Abe, J. A. . (2020). Big five, linguistic styles, and successful online learning. Internet and Higher Education, 45(1). https://doi.org/10.1016/j.iheduc.2019.100724.

Anggraini, Y., Patmanthara, S., \& Purnomo. (2017). Pengaruh Lingkungan Belajar Dan Disiplin Belajar Terhadap Hasil Belajar Kompetensi Keahlian Elektronika Industri Di Sekolah Menengah Kejuruan. Jurnal Pendidikan: Teori, Penelitian, Dan Pengembangan, 2(2), 1650-1655. https://doi.org/10.17977/jptpp.v2i12.10316.

Anugrahana, A. (2020). Hambatan, Solusi dan Harapan : Pembelajaran Daring Selama Masa Pandemi Covid-19 Oleh Guru Sekolah Dasar. Jurnal Pendidikan Dan Kebudayaan, 10(3), 282-289. https://doi.org/10.24246/j.js.2020.v10.i3.p282-289.

Asmuni, A. (2020). Problematika Pembelajaran Daring di Masa Pandemi Covid-19 dan Solusi Pemecahannya. Jurnal Paedagogy, 7(4), 281. https://doi.org/10.33394/jp.v7i4.2941.

Chang, T. Y., Hong, G., Paganelli, C., Phantumvanit, P., Chang, W. J., Shieh, Y. S., \& Hsu, M. L. (2020). Innovation of dental education during COVID-19 pandemic. Journal of Dental Sciences, 155. https://doi.org/10.1016/j.jds.2020.07.011.

Chen, G., He, J., Cai, Z., \& Fan, X. (2020). Perceived parenting styles and body appreciation among Chinese adolescents: Exploring the mediating roles of dispositional mindfulness and self-compassion. Children and Youth Services Review, 119. https://doi.org/10.1016/j.childyouth.2020.105698.

Cynthia, L. C., Martono, T., \& Indriayu, M. (2015). Pengaruh Fasilitas Belajar dan Motivasi Belajar Terhadap Prestasi Belajar Mata Pelajaran Ekonomi Siswa Kelas XI IIS di SMA Negeri 5 Surakarta Tahun Ajaran 2015/2016. Jurnal Pendidikan Bisnis Dan Ekonomi, 1(2), 1-20. http://jurnal.fkip.uns.ac.id/index.php/ptn/article/view/7397/5169.

De Brouwer, E., Raimondi, D., \& Moreau, Y. (2020). Modeling the COVID-19 outbreaks and the effectiveness of the containment measures adopted across countries. MedRxiv, 3, 1-9. https://doi.org/10.1101/2020.04.02.20046375.

Dianah, L. (2017). Kontribusi Fasilitas dan Disiplin Belajar Terhadap Hasil Belajar Siswa 
dalam Pembelajaran IPS. JSSH (Jurnal Sains Sosial Dan Humaniora), 1(2), 51. https://doi.org/10.30595/jssh.v1i2.1478.

Handayani, E. S., \& Subakti, H. (2020). Pengaruh Disiplin Belajar terhadap Hasil Belajar Bahasa Indonesia di Sekolah Dasar. Jurnal Basicedu, 5(1), 151-164. https://doi.org/10.31004/basicedu.v5i1.633.

Haryuni, S. (2013). Penerapan bimbingan konseling pendidikan dalam membentuk kedisiplinan layanan bimbingan pengembangan diri. Jurnal Penelitian Pendidikan Islam, 8(3), 389-416. https://doi.org/10.21043/edukasia.v8i2.760.

Hwang, G. J., Wang, S. Y., \& Lai, C. L. (2020). Effects of a social regulation-based online learning framework on students' learning achievements and behaviors in mathematics. Computers and 160. https://doi.org/10.1016/j.compedu.2020.104031.

Intan, F., \& Hidayat, W. (2018). Hubungan Antara Keaktifan Belajar Siswa Terhadap Kemampuan Komunikasi Siswa SMK. Jurnal Visipena, 10(2), 1-15.

Khodabakhsh, M. R., Kiani, F., \& Ahmedbookani, S. (2014). Psychological Wellbeing nd Parenting styles as prdictors of mental health. International Journal of Pediatrics, 2(9), 39-46.

Luo, Y., Chen, F., Zhang, X., Zhang, Y., Li, Y., Zhou, Q., \& Wang, Y. (2020). Profiles of Maternal and Paternal Parenting Styles in Chinese Families: Relations to Preschoolers 02019; Psychological Adjustment. Children and Youth Services Review. https://doi.org/10.1016/j.childyouth.2020.105787.

Mabuka, O. (2021). Tata Tertib Sekolah Berperan Sebagai Pengendali Perilaku Siswa di SD Inpres Raja Kecamatan Morotai Selatan Barat. Jurnal Ilmiah Wahana Pendidikan, 7(1), 360-372. https://doi.org/10.5281/zenodo.4724351.

Mulyati, S., \& Evendi, H. (2020). Pembelajaran Matematika Melalui Media Game Quizizz Untuk Meningkatkan Hasil Belajar Matematika Smp 2 Bojonegara. Jurnal Pendidikan Matematika, 03(01), 64-73. https://doi.org/http://dx.doi.org/10.30656/gauss.v3i1.2127.

Novalinda, R., Prima, F. K., Mallisza, D., \& Ambiyar, A. (2020). Pengaruh Pembelajaran Berbasis Entrepreneurship Dan Disiplin Belajar Terhadap Hasil Belajar Manajemen $\begin{array}{lllll}\text { Optik. } & \text { Edukasi: } & 192 .\end{array}$ https://doi.org/10.31571/edukasi.v18i2.1859.

Nur, A. S. (2016). Pengaruh Pola Asuh Orang Tua, Konsep Diri, dan Motivasi Berprestasi terhadap Prestasi Belajar Matematika Siswa Kelas IX SMP Negeri di kota Merauke. Suska Journal of Mathematics Education, 2(2), 89 - 96. https://doi.org/10.24014/sjme.v2i2.2067.

O’Doherty, D., Dromey, M., Lougheed, J., Hannigan, A., \& Last, J. McGrath1, D. (2018). Barriers and solutions to online learning in medical education - an integrative review. BMC Medical Education, 18(130), 1-11. https://doi.org/10.1186/s12909-018-1240-0

Pada, A. (2021). Pengaruh Pola Asuh Orangtua Terhadap Hasil Belajar Siswa Kelas IV Sekolah Dasar. Jurnal Ilmiah Ilmu Kependidikan, 5(2), 375-386. https://doi.org/10.26858/jkp.v5i2.20912.

Pucangan, K. dkk. (2017). Hubungan Antara Konsep Diri Dan Pola Asuh Orang Tua Terhadap Hasil Belajar IPA Siswa Kelas V SD di Desa Selat. Jurnal Mimbar PGSD Universitas Pendidikan Ganesha, 5(2), 1-10. https://doi.org/10.23887/jjpgsd.v5i2.11007.

Puncangan, K. Y. J. (2017). Hubungan Antara Konsep Diri Dan Pola Asuh Orang Tua Terhadap Hasil Belajar SD Kelas II. Journal PGSD Universitas Pendidikan Ganesha, 5(2), 1-11. https://doi.org/10.23887/jjpgsd.v5i2.11007.

Siegal, D. M., Curnutte, J. T., Connolly, S. J., Lu, G., Conley, P. B., Wiens, B. L., \& 
Crowther, M. A. (2015). Andexanet alfa for the reversal of factor Xa inhibitor activity. New England Journal of Medicine, 374(25), 2413-2424. https://doi.org/10.1056/NEJMoa1510991.

Sourial, N., Longo, C., Vedel, I., \& Schuster, T. (2018). Daring to draw causal claims from non-randomized studies of primary care interventions. Family Practice, 35(5), 639643. https://doi.org/10.1093/fampra/cmy005.

Sourial, N., Longo, C., Vedel, I., \& Schuster, T. (2018). Daring to draw causal claims from non-randomized studies of primary care interventions. Family Practice, 35(5), 639643. https://doi.org/10.1093/fampra/cmy005.

Surya Erofiana, A., Santoso, G., \& Nomi, S. (2021). Studi Penggunaan Game Online Free Fire Pada Emosi Siswa Kelas 5 Di SDN 2 Braja Harjosari. Jurnal Pendidikan Guru Sekolah Dasar, 3(1). https://jurnal.stkipbjm.ac.id/index.php/pgsd/article/view/1270.

Vélez-Agosto, N. M., Soto-Crespo, J. G Vizcarrondo-Oppenheimer, M., Vega-Molina, S., \& García Coll, C. (2017). Bronfenbrenner's Bioecological Theory Revision: Moving Culture From the Macro Into the Micro. Perspectives on Psychological Science, 12(5), 900-910. https://doi.org/10.1177/1745691617704397.

Wardani, W. (2021). Pengaruh Lingkungan Belajar, Fasilitas, dan Metode Mengajar Guru melalui Motivasi terhadap Hasil Belajar. Journal of Education, Humaniora and Social Sciences (JEHSS), 3(3), 1307-1315. https://doi.org/10.34007/jehss.v3i3.553.

Wulandari, E. T. (2019). Pentingnya Pengaruh Fasilitas Belajar Terhadap Prestasi Belajar Siswa The Importance of the Effect of Learning Facilities on Student Learning Achievement. VI, 20, . EProsiding Seminar Nasional Biologi, 6(20), 258-261. http://103.76.50.195/semnasbio/article/view/10545. 